\title{
THE MOLECULAR BASIS OF PRIVATE PROPERTY
}

\author{
Kyle J. MAMOUNIS - Walter E. BLOCK \\ (Received: 28 March 2018; revision received: 21 November 2018; \\ accepted: 6 December 2018)
}

For political and economic theory in general, libertarianism in particular, property rights are a pillar of central importance. One might describe the schools of political and economic thought solely by their approach to property rights, for example libertarianism as expansive and communism as constrained, with a fair degree of accuracy on the system as a whole.

Despite centuries of property rights philosophy, a fundamental weakness persists that can be most easily seen from a natural science perspective. Property classifications, such as between one's physical body, personal property, and other types of so-called private property, underlie much of the property rights theory, yet these classes are more of a result of technological limitations than philosophical or real economic distinctions.

We demonstrate through a lens of molecular and developmental biology how distinctions between types of property are misguided or illusory. Using the developing human embryo as the most basic example of property acquisition, we show that all subsequent examples of greater property acquisition and its use are fundamentally the same. The point is further developed with other biological examples.

Foundational concepts are of primary importance as their mistake persists through even the most elegant deductions. In order to defend itself from the political and economic attacks, the property rights ethic must be consistent and logical. For this, any artificial or contradictory concepts must be shed.

Keywords: property rights, economics, political theory, libertarianism, legal theory

JEL classification index: Q59

Kyle J. Mamounis, corresponding author. Postdoctoral Fellow at University of Central Florida, Burnett School of Biomedical Sciences, Orlando, USA. E-mail: kyle.mamounis@ucf.edu

Walter E. Block, Professor at Loyola University New Orleans, USA. E-mail: wblock@loyno.edu 
A well-developed institution of private property differentiates Western civilization from non=civilized societies. Despite the length of time this tradition has existed and its nearly ubiquitous observation in social interactions, the definition of private property, its moral justification, and the limits to be placed on it are the perennial subject of argument within and between the political and economic schools of thought.

\section{TYPES OF PROPERTY}

In The Communist Manifesto, Marx distinguishes between "property in general" and "bourgeois property." He saw no need to abolish property in general, such as:

"Hard-won, self-acquired, self-earned property...the property of petty artisan and of the small peasant, a form of property that preceded the bourgeois form." (Marx and Engels 1992: 23)

Bourgeois property, on the other hand, is

"property in its present form...based on the antagonism of capital and wage labour." (Marx and Engels 1992: 24)

It is to say that those items made or used personally are a legitimate form of property, while those acquired through capital deployment or not personally laboured on are not. Marx and his protégés further developed distinctions between "personal" and "private" property. The former consisted of ones' portable effects (clothes, tooth brush, driven cattle) or fixed, inhabited property, such as a lived-in domicile or worked-on farm. Private property is just about anything else; specifically the property that renders profit to the owner or that is contained in the famous phrase of "means of production." Although Marx's ideas on property are not taken seriously in modern legal systems, they persist as mental frameworks. This can be most easily illustrated with a thoughtful experiment about taxation, which is the expropriation of private property by the state. Would a tax on the $\mathrm{CO}_{2}$ emissions from your car be thought of in the same way as one on the $\mathrm{CO}_{2}$ emissions from your body? As another example, taxes are almost always paid in money today, though in the past centuries may have been paid in agricultural or other products. How would a blood tax (supposing there was some economic justification for it), where once a month all citizens must report to a government phlebotomy centre to render $5 \%$ of their blood volume as part of their civic duty, be looked upon? It, almost certainly, would be looked at as more onerous than a money tax. 
In this regard, let us consider property rights economics. Intermediate microeconomics textbooks constitute a good summary of the views of the profession on many issues of interest. However, if you look at the indices of most mainstream texts, you will rarely find an entry for "property rights." Thus, this concept, which really should be the basis of virtually all of economics, occupies a sort of "bandit-like" existence in the dismal science. The only real exception to this general rule emanates from Coase (1960), Posner $(1987,1992)$ and Demsetz (1967, 1979), and their so-called "law and economics" tradition. Here, property rights are indeed studied intensively.

However, this is done problematically. A typical offering from this school of thought within economics is that when it costs little to define and defend property rights, they will be prevalent; for example, pencils, automobiles, shoes, etc. In contrast, when it is expensive to do so, then this foundation of not only economics, but, indeed, civilization, will not come into being. The examples offered in this regard stem from new innovations (such as radio and television, ${ }^{2}$ the web), land, when it was superfluous in the past, and also bodies of water. Sometimes, this phenomenon is even illustrated by a sort of supply and demand curve, with costs on the vertical axis and amount, extent, and quantity of property rights on the horizontal axis, and the two are related with a downward sloping quasi demand curve.

What is wrong in this way of looking at the matter? Consider the demand curve for bread. It, too, is downward sloping, indicating that the lower the price of this food staple, the more of it will be desired to be purchased. Where do property rights fit in, in this presentation? They are implicit; we are invited to assume that someone owns the bread (those behind the supply curve), and that the customers own the money with which they are contemplating to purchase this item (those behind the demand curve). The difficulty with placing property rights on the horizontal axis is that this assumption can no longer hold, since the very essence of market transaction, property rights varies along this axis. Later, we will see that this economic assessment of property rights is simply a technological problem, one that can and will shift, and is, therefore, no answer to a question of rights at all.

Distinctions between the types of property were not novel to Marx and Engels. The Summa Theologica, Thomas Aquinas (1912) discourses on the resolution of whether it is natural for man to possess "external things." The primary objection addressed: 
"It would seem that it is not natural for man to possess external things. For no man should ascribe to himself that which is God's. Now the dominion over all creatures is proper to God, according to Psalm 23:1, "The earth is the Lord's," etc. Therefore it is not natural for man to possess external things.” (Aquinas 1912: II-II, Q. 66, Art. 1)

Clearly, the question of what material can be justifiably owned by a man has been around as long as nearly any other philosophical question. What does Aquinas mean by the "external things?" Presumably, this refers to a distinction between the material of a man's physical body and all other objects.

The concept of an absolute property right in one's own physical body holds in modern times. It underpins the right to put, supposedly, harmful substances, such as drugs ${ }^{3}$ or, famously, unpasteurized milk, ${ }^{4}$ into one's body. It also directs the particularly heinous category into which the crimes of assault, rape, and murder inhabit, as they constitute brutal violations of property rights on one's physical body.

Philosophy has attempted to discover and codify laws that would explain the seeming self-evidence of property rights. ${ }^{5}$ Political science has attempted to draw lines between the types of property that may have no rational basis, for the purpose of isolating particular types for expropriation. A unified theory has not, as yet, been produced that equally justifies all types of property within the same conceptual framework.

Thus, the concept of property has been inhabited in three general categories: 1) personal/internal, that is a man's own physical body, 2) personal/external, that is one's portable and/or used possessions and land, and 3) bourgeois/profitable/ absentee landlord, that is the fixed property, such as land and capital equipment, or both that is not personally laboured on by the owner, yet renders him profit. These categories are not thought of technically, but are rather the instincts of most people, who would say that your right to your own body has more legitimacy than your right to your car, which itself has even more legitimacy than your right to your factory. Again, to test this, imagine the reaction of a proposed tax on one and then on the others. In the following section, we demonstrate that there is no natu-

3 Most defenses of legalized drugs focus on utilitarian considerations. For those that look at the matter in the deontological sense employed in the present paper, see Block $(1993,1996)$; Block et al. (2003); Cussen - Block (2000); Obioha - Block (2012); Szasz (1985, 1992); Thornton (1991); and Vance (2012).

4 According to milk.procon.org, 20 states in the US maintain criminalization of raw milk sales, while the rest regulating how and where it can be sold. In 2009, U.S. Congressman Ron Paul introduced HR 778 "to authorize the interstate traffic of unpasteurized milk and milk products that are packaged for direct human consumption."

$5 \quad$ See Rand (1957); Rothbard (1973, 1982a, 2011); Nozick (1974); Kinsella (1995, 1996); Bergland (1986); Narveson (1988); Hoppe (1993); Block (2009) and Huebert (2010). 
ral or logical basis for the distinctions between the types of property. Specifically, we will argue that the processes by which a man acquires his physical body are identical in kind by which he acquires property external to his physical body. The property rights principle by which all property can be unified in definition and justification will be centred on acquisition and manipulation, as the fundamental and dynamic laws of the natural world, respectively.

\section{PROPERTY ACQUISITION OF MAN, BEGINNING AT CONCEPTION}

Conception is the event wherein ownership of the mother's and father's sex cells or gametes, previously their respective property, is transferred to a third party (the child) at the same time that these cells are used to produce that third party. Man's most fundamental property, his own physical body, is built through a continuous process from conception, passing through identifiable but non-static phases.

This event is not mystical but rather observable through the fertilization, a slow hyper-polarization and then repolarization of a fertilized oocyte, usually occurring within one to two hours after insemination. Thus, a new individual physical body, approximately $100 \mu \mathrm{m}(0.1$ millimeter $))$ in diameter and $4 \mu \mathrm{g}$ (0.004 milligram) in weight, is created. The zygote has a unique set of chromosomes, derivative of, yet distinct, from mother and father, and a blood type that can differ from the mother's despite not yet having blood or blood vessels. Between 24 and 30 hours after the initiation of fertilization, cellular cleavage begins and progresses as the developing blastocyst moves from the uterine tube to the endometrium for implantation. The embryo continues to grow, and a series of divisions creating tripartite specialized tissues called gastrulation begins. By the $8^{\text {th }}$ week, the embryo increases to 160 times in length and 250,000 times in weight to approximately $1.6 \mathrm{~cm}$ and $1 \mathrm{~g}$, respectively. Tissue differentiation, organogenesis, and growth continue until birth, with the foetus increasing another 32 times in length and 3,500 times in weight.

The purpose of giving an overview of this process is to ask the following question: from whence comes this increase in the body's mass and energy to produce and differentiate it? Initially, non-sperm seminal fluid and latent cytoplasmic substrate in the oocyte provide nutrition. Fairly early, however, the zygote relies on nutrition from the fallopian tubes, and then more heavily on resources at the endometrium. Macro- and micro-nutrients, as well as metabolic gasses, pass from mother's blood through the placenta to the umbilical cord where they surround and are absorbed by the foetal cells. These nutrients become part of the growing foetus, or are used as energy for growth and development processes. The placenta also produces protein and steroid hormones as growth factors for the foetus. 
In short, everything the embryo uses to develop its physical body is sourced externally. ${ }^{6}$ Were it removed from the uterus and placed in a non-nutritive container, growth would not occur, as the required resources for its growth are not intrinsic to it. All cells, from the simplest bacterium to the most complex multicellular animal, require external material and energy in order to build and maintain their physical bodies.

\section{ALL PROPERTY IS SOURCED EXTERNALLY}

Just as in the developing embryo, all property, that is any type or possible conception of material property, is sourced externally. Man's physical body, whether mature or nascent, is built and fuelled with materials external to it. As a man's meal is sourced from outside of his body, so is the breast milk to nourish an infant, and the nutrition an embryo is provided in utero. At the cellular level, the zygote, morula, gastrula and so on obtain nutrients from their environment through absorptive processes, as a man procures a meal from his environment through ambulatory and dexterous ones. Moreover, when a developed human ingests a meal, the processes by which intestinal enterocytes absorb nutrients are the same ones, with minor differences, as used by embryonic cells. Characteristic nutrientuptake proteins, such as the GLUT family of hexose transporters are present and function similarly in embryonic as well as in adult cells.

If all property is sourced from external materials, how does a distinction between the types arise? To distinguish between internal and external property from its origin, as we have seen, is impossible. Does the end use of property, then, determine its type? If a man either eats an apple, or uses it as a model for a still life painting, can it be said that the apples of these two events inhabit different categories of property? Was the man's purchase from the grocer any different? Between "personal" external property and "private" external property, the challenge is the same. Do the intentions of a land buyer, whether to speculate, rent, or personally work on the land determine the legitimacy of his purchase? Legitimacy of property from its use, rather than its acquisition, is not a workable system of property rights. Who would determine whether the use is legitimate or not? The power to render judgment of legitimate versus illegitimate property usage requires an implicit claim on the property prior to that of the owner, obviating and rendering the title of the "property owner" as meaningless.

6 Why, then, do our parents and theirs infinitum own us, since we were all created with material owned by them. For attempts to wrestle with this question see Steiner (1994: 242-248), Kinsella (2006), and Block (2016). 
Legal systems focus, by necessity, on the acquisition side of property for the determination of legitimacy. The police, when chasing a mugger making off with a purse, does not inquire about the use he has in mind for it. Oppenheimer described the "economic" versus "political" means of resource acquisition (Oppenheimer 1908). Trade and gift, free from coercion, form the economic means, while all coerced resource transfers form the political. This is the most clear and consistently applicable rule for legitimacy of property.

Once a theory of property acquisition is accepted as the determination of legitimacy of ownership, the remaining question is between internal and external sourcing of property. Through regression, it can be seen that all property, both internal and external. is initially acquired from the external. If acquisition is to be used to describe property, then internal and external distinctions are illusions.

\section{OBJECTIONS AND ANSWERS}

Objection: There is a difference between personal and private property, as well as internal and external, as the Marxists argue. The difference is that private property produces a gain of more property, whereas personal property does not. A factory, by definition, produces a return for its owner, whereas a house or car is a simple consumer good that depreciates in value as the owner consumes it. The physical body, likewise, does not produce wealth for a man. It is an absolute requirement for his existence. Therefore a distinction between what a type of property can produce for its owner can be made, and this distinction allows for difference in ethical and political considerations between the types of property.

Answer: Viewing some property as productive or with ability to render return, and other property as unproductive, is an erroneous perspective rather than a true distinction. At the smallest scale, the embryo is indeed productive as it produces more of itself so that its owner can develop into a mature human. A human cell is simply a microcosm of a machine tool factory, bringing in exogenous raw materials and energy to produce other things.

Outside of a man's physical body, the distinction between productiveness in personal versus private property is also spurious. At first glance, a factory or mine produces a return, whereas a house or car does not. At second glance, however, that statement is not a priori truth. Factories and mines can lose money, or sit vacant while still on the owner's books. A house can give a return if rented, and a car if driven as a taxi. If a man lives in a house for half of the year and rents it out for the other half, is he in possession of personal property from January to June and private property from July to December? 
A limited technological perspective underlies this misunderstanding. Fast progress can be observed towards the technological ability to produce an audio or video recording with a device that can fit in a pants pocket, however, that would have required a medium sized specialized building, several workers, and thousands of pounds of technical equipment decades ago. Is a smart phone private property, or is it a personal property of a recording studio? Small milling CNC machines and 3D printers will replace large-scale factories for the production of many items, and they will be affordable for millions of people. The distinction between personal property and the means of production only makes sense in a static world where technological facts cannot change. It is a statement, therefore, of the factual state of technology rather than a true statement of the existence of fundamentally different types of material property. It can be further said that property, by definition, is subjectively productive to its owner, and that no objective standard for productiveness seems apparent.

Objection: The distinction between internal and external property is real. When a man eats an apple, it moves from external to internal property through the processes of ingestion, digestion, and absorption. Unlike putting an apple in a pantry, where it can be retrieved in the same state as it was placed, the molecular digestive processes that transform external property to internal property permanently alter the material involved. A toothbrush or automobile can be taken from its owner without invading their physical body; internal property requires invasive means to remove. Therefore internal and external property, that is a man's physical body compared to any other property he may claim, are fundamentally different and should be viewed as ethically and politically distinct.

Answer: This assertion is also based on a technological limitation rather than a fundamental distinction. ${ }^{7}$ It is technically feasible to remove glucose, mineral ions, proteins, etc. from blood; it is not done because it is not economically efficient. Endoscopy can remove material from the gastrointestinal tract. There was a time when state revenue required the infamous tax collector. Quotas were given to the collector based on crude estimates of the wealth generated in a given area, since records of every transaction between farmers, cobblers, barbers, etc. was impossible. In modern times, the idea that metrics of economic activity are impossible and taxes would need to be collected based on a crude quota system imposed by a man on foot is laughable. In time, technology will allow removal and

7 We do not deny that it is possible to distinguish between different types of property, only that these distinctions are not fundamental. For example, there is big property (elephants) and small property (mice), there is property that begins with the letters A-M (apples, dogs), and that which begins with the letters N-Z (pickles, zebras), etc. But these are hardly fundamental differences. 
addition to the physical body in a way that is unimaginable today. Does such an invention change the nature of property in one's physical body, or is the current distinction simply a result of limited information? As a foodstuff is altered during ingestion, and cannot be removed and returned to its original state with current technology, so are most of the materials used in the industrial processes. Houses, cars, and televisions cannot have their component materials removed in their raw state anymore, unlike the last night's dinner.

\section{THE BOUNDARIES OF THE PHYSICAL BODY}

What are the natural boundaries of a man's physical body? Is the sum total of a man's living cells his physical body? What are the dead cells of the epidermis, hair, and nails? The skin and the gastrointestinal tract are colonized by microbes; do these non-human cells count as part of the body? The gastrointestinal tract itself can be considered as outside of the body, as the central walls of an inner tube do not represent the "inside" of the tube, where the air inflates. Intestinal bacteria ferment some fibres that are difficult to digest by humans into short chain fatty acids, which are absorbed and used by enterocytes. If this process is performed outside of the body as in sauerkraut or yogurt and the product ingested, does that change the property relationship between the bacteria, the human, and the food? For mushrooms of the fungal kingdom that secrete digestive enzymes outside of their bodies and absorb the broken down nutrients; is the property relationship changed by external or internal digestion of food?

Similarly, "external" tools used by humans and other animals are analogues of the internal tools of the cell. During glycolysis, 9 or 10 enzymes process glucose into a form suitable for the greatest energy harvest. At the tissue level, exocrine secretions into the gut lumen act as tools to break down large molecules like starches into smaller glucose monomers for absorption. Hands, eyes, and mouth are employed to introduce the foodstuff into the system. Before any of this, however, external tools are used to grow the food, harvest it, and cook if it needs to be cooked, etc. If you are an observer, the size of an enzyme and the inner workings of the cell would look like industrial tools. Alternatively, if you are an observer, the size of a planet and industrial human tools would look like the inner workings of the cell. Regardless of scale and position, internal or external to the organism, material used in pursuance of goals inhabits the same property relationship with the owner. Man, with a highly developed brain capacity of abstract thoughts, has outsourced the majority of his survival strategy to external tools. A clear line of distinction cannot be drawn between these external and internal property uses. 
There are numerous non-human examples of this biological outsourcing. Many animals use gut microbiota as humans do; famous examples include termites and ruminants that use bacteria, archaea and protozoa to digest cellulose. Non-human primates and other animals use tools and construct shelters. In some cases, the line between shelter and physical body is particularly difficult to draw. The shell of a turtle or of a mollusc is built by the animal but is not a living part of their body when it is finished and in use. Is there any difference relevant to property rights between chewing, spitting out, or otherwise secreting your building materials versus mixing concrete or plaster?

\section{CONCLUSION}

The thought tradition of distinguishing the types of property is erroneous and based on insufficient knowledge of the natural world. Its effect has been to isolate some property types from others in order to be plundered by the political class. Material property is acquired in the same fashion from the microscopic scale up to the corporate or collective, as the intentional manipulation of matter in order to achieve a given end. The only rational distinction that can be made regarding property is the manner in which it is obtained; specifically, is it obtained through coercion or not? The Marxist paradigm, as well as its variations and descendants, fails as a useful description since the "means of production" change over time, usually into smaller and smaller units capable of being owned and operated by more and more individuals. The distinction between internal and external property fails for a related reason, which is that all material within a man's physical body is acquired external to it. Defining the boundaries of the physical body is, at a high enough resolution, more esoteric than scientific.

As technology and the understanding of the natural world progress, many ideas about material property are exposed as simple misunderstandings of physical nature. With the logical base for distinctions of the property type removed through enhanced technological knowledge, all that remains is the fact that rules and regulations about property are schemes to siphon resources to the political class. The right to property is either an all-encompassing basket extending as far as just acquisition will allow, or a weak concept vulnerable to erosion. Property rights exist, or they do not exist, there is no third option.

\section{REFERENCES}

Bergland, D. (1986): Libertarianism in One Lesson. U.K.: Orpheus Publications. 
Block, W. E. (1993): Drug Prohibition: A Legal and Economic Analysis. Journal of Business Ethics, 12: 689-700. https://link.springer.com/article/10.1007/BF00881383

Block, W. E. (1996): Drug Prohibition, Individual Virtue and Positive Economics. Review of Political Economy, October, 8(4): 433-436. http://www.tandfonline.com/doi/ abs/10.1080/09538259600000077

Block, W. E. (2009): The Privatization of Roads and Highways: Human and Economic Factors. Auburn, Alabama: The Mises Institute. http://www.amazon.com/Privatization-Roads-AndHighways-Factors/dp/1279887303/ref=sr_1_1?s=books\&ie=UTF8\&qid=1336605800\&sr=11; available for free here: http://mises.org/books/roads_web.pdf

Block, W. E. (2016): How We Come to Own Ourselves. Polish Academic Journal - Societas et Ius, 5:7-14. http://apcz.umk.pl/czasopisma/index.php/SeI/article/view/SEI.2016.001

Block, W. E. - Wingfield, K. - Whitehead, R. (2003): Re-Evaluating America's Failing Drug Control Laws: A Legal, Philosophical, and Economic Proposal. Oklahoma City Law Review, 28(1): 119159. http://141.164.133.3/faculty/Block/Articles\%20for\%20web/Drug\%20control\%20Laws.doc

Coase, R. H. (1960): The Problem of Social Cost. Journal of Law and Economics, 3: 1-44. http:// www.sfu.ca/ allen/CoaseJLE1960.pdf

Cussen, M. - Block, W. E. (2000): Legalize Drugs Now! An Analysis of the Benefits of Legalized Drugs. American Journal of Economics and Sociology, 59(3): 525-536.

Demsetz, H. (1967): Toward a Theory of Property Rights. American Economic Review, 57(2): $347-359$.

Demsetz, H. (1979): Ethics and Efficiency in Property Rights Systems. In: Rizzo, M. (ed.): Time, Uncertainty and Disequilibrium: Explorations of Austrian Themes. Lexington, Mass.: Lexington Books, D.C. Heath and Company, pp. 97-116. http://ncachanosky.files.wordpress.com/2009/08/ rizzo-mario-ed-1979-time-uncertainty-and-disequilibrium-exploration-of-austrian-themes.pdf

Hoppe, H. H. (1993): The Economics and Ethics of Private Property, Studies in Political Economy and Philosophy. Boston: Kluwer.

Huebert, J. (2010): Libertarianism Today. Santa Barbara, CA: Praeger.

Kinsella, S. (1995): Legislation and the Discovery of Law in a Free Society. Journal of Libertarian Studies, No. 11(2): 132-181.

Kinsella, S. (1996): New Rationalist Directions in Libertarian Rights Theory. Journal of Libertarian Studies, 12(2): 313-326, Fall. http://www.mises.org/journals/j1s/12_2/12_2_5.pdf

Kinsella, S. (2006): How We Come to Own Ourselves. Mises Institute, Mises Daily Articles, September 7, http://www.mises.org/story/2291

Marx, K. - Engels, F. (1992): The Communist Manifesto. Oxford: Oxford University Press.

Narveson, J. (1988): The Libertarian Idea. Philadelphia: Temple University Press.

Nozick, R. (1974): Anarchy, State and Utopia. New York: Basic Books.

Obioha, V. - Walter, E. B. (2012): War on Black Men: Arguments for the Legalization of Drugs. Criminal Justice Ethics, 31(2): 106-120. http://www.tandfonline.com/doi/pdf/10.1080/073112 9X.2012.719671

Oppenheimer, F. (1975): The State. New York: Free Life Editions.

Posner, R. A. (1987): The Law and Economics Movement. American Economic Review, 77(2): $2-13$.

Posner, R. A. (1992): Economic Analysis of Law. Boston: Little Brown (4 ${ }^{\text {th }}$ ed.)

Rand, A. (1957): Atlas Shrugged. New York: Random House.

Rothbard, M. N. (1973): For a New Liberty. New York: Macmillan.

Rothbard, M. N. (2011): Economic Controversies. Auburn, Alabama: Mises Institute. http://library. mises.org/books/Murray\%20N\%20Rothbard/Economic\%20Controversies.pdf

Steiner, H. (1994): An Essay on Rights. Oxford: Blackwell. 
Szasz, T. S. (1985): Ceremonial Chemistry: The Ritual Persecution of Drugs, Addicts, and Pushers. Holmes Beach, Fla.: Learning Publications.

Szasz, T. S. (1992): Our Right to Drugs: The Case for a Free Market. New York: Praeger.

Thomas, A. (1912): The Summa Theologica of St. Thomas Aquinas. London: Burns Oates \& Washbourne.

Thornton, M. (1991): The Economics of Prohibition. Salt Lake City, University of Utah Press.

Vance, L. (2012): The War on Drugs Is a War on Freedom. Orlando, Fl.: Vance Publications. https:// www.amazon.com/War-Drugs-Freedom/dp/0982369751/ref=tmm_pap_swatch_0?_encoding= UTF8\&qid=1494421483\&sr=8-1 